\title{
A Gendered Analysis on Adaptation to Resettlement Stress: Case Studies from Deduru Oya Reservoir Project in Sri Lanka
}

\author{
M.M.J.G.C.N. Jayasiri*, D.M.N. Diyawadana, S.M.L.D. Samarakoon \\ S. Pathmarajah ${ }^{1}$ and N.D.K. Dayawansa ${ }^{1}$
}

Postgraduate Institute of Agriculture

University of Peradeniya

Sri Lanka

\begin{abstract}
Dam constructions and flow modifications lead a nation towards significant development. Other than expected positive outcomes, a dam can contribute to severe negative impacts on society and environment. Displacement and resettlement due to dams affect the communities adversely. Displacement affects males and females differently as each gender is assigned with specific roles that lead to different responses. Though, many large dam projects such as Mahaweli have been undertaken in Sri Lanka, gendered responses to resettlement stress has not been adequately documented. Therefore, this study attempted to analyse the responses to seven identified resettlement stress factors by each gender using twelve case studies from Deduru Oya reservoir project in Sri Lanka. The resettlement stress factors under consideration were landlessness, unemployment, homelessness, marginalization, food insecurity, loss of access to common properties and social disintegration. For the issues of landlessness, unemployment and homelessness, males take longer time to adapt since they tend to secure a permanent livelihood while females find immediate possible solutions for issues such as feeding children and caring for family. Even though both genders are marginalized within the new community, women are more affected due transfer of land ownership completely to men. The traditional reproductive gender roles that females have to play amidst the resettlement stress place tremendous pressure on them. No provisions have been made to meet females' practical and strategic needs in the resettled environment. In addition, patriarchal way of land reallocation makes females marginalised within the family itself.
\end{abstract}

Keywords: Adaptation, gender, Deduru Oya reservoir, displacement, resettlement stress

\section{INTRODUCTION}

Dam construction leads a nation towards a significant development and provides numerous and valuable benefits to mankind (WCD, 2000; Acreman, 2000; Ledec and Quintero, 2003). Other than expected positive outcomes, a dam contributes to several negative impacts in terms of social and environmental impacts. Considering the impacts of large dams, the World Commission on Dams (WCD) states that, "In too many cases an unacceptable and often unnecessary price has been paid to secure some benefits, especially in social and environmental terms, by people displaced, by communities downstream, by taxpayers and by natural environment" (WCD, 2000).

\footnotetext{
1 Department of Agricultural Engineering, Faculty of Agriculture, University of Peradeniya, Sri Lanka

* Corresponding author: nishanka.jayasiri@gmail.com
} 
Construction of large dams has been led to displacement of 40 to 80 million people worldwide, most of the time it has been done force fully (WCD, 2000; Caspary, 2007). This figure only presents the extent of displacement, without explaining the real social impacts, together with presence of huge variation from case to case and all of them are sensitive cases regarding humanity. The benefits of such project are usually assessed in-terms of monetary value however, it does not address the uneven benefit sharing. Displacement does not limit to physical displacement, but it extends even to livelihood displacement. Physical displacement by a dam construction is the displacement of people from their original location to a new place. Most of the livelihoods depend on the natural resources and therefore, the livelihood is directly linked with the land they live. With dam construction, these resources can be inundated or inaccessible and resulting in livelihood displacement. Normally large dam projects do not deal with participatory approaches, resettlements or compensations (WCD, 2000). However in Sri Lanka, generally resettlement and compensation take place though there are many complains on reasonability of them (Ministry of Resettlement, 2013). When the physical resettlement or compensation happens they are lesser in value compared to the loss and also it takes a long time to compensate. In addition, compensation and resettlement are belonged to those who have legal titles, leaving out a large number of people such as tenant farmers and marginalized groups such as women and indigenous peoples. However, the universal declaration of human rights (UN, 1948) accepts that everyone has the right to better living standards (adequate for the health and well-being), right to cultural life, right to freedom of movement and residence, right to not to be interfered with his or her privacy, right to not to be arbitrarily deprived of his or her property, right to social security right to free choice of employment as well as it accepts the family as an important social unit that everyone has. But these rights of displaced people are in question.

Gender refers to the socially constructed characteristics of women and men; such as norms, roles and relationships of and between groups of women and men. In most societies lowincome women have a triple role: women undertake reproductive (biological reproduction and also the care and maintenance of the work force), productive (work done by both men and women for pay), and community managing activities (voluntary unpaid work, undertaken during 'free' time), while men primarily undertake productive and community activities. Since men and women play different roles, they often face very different cultural, institutional, physical and economic constraints, many of which are rooted in systematic biases and discrimination (ILO, 1998).

In the case of displacement, women are the group considered as vulnerable to bad effects of the project due to the instability occurring in specific gender roles assigned to them regarding production and reproduction (Mehta, 2011; Godamunne, 2012; Asthana, 2012). Mainly the effects on women have links with surrounding natural resources including water resources to fulfil her day to day requirements and simple ways of income generation. Dam construction or similar development projects break these links affecting food security and sanitary requirements of families. There are many policies and policy guidelines in different countries regarding resettlement but most of them are gender blind. In most of the policies women are considered as second class citizens and assumed the benefits goes to male household head are automatically transferred to the whole family (Mehta, 2011). Further, the man is considered as the project affected person and woman is considered as a dependent. According to Indian resettlement policy, any notice regarding to resettlement should be informed to the male household head or to elder male if he is absent. But if there are no males, the notice should be stuck on the door or public place indicating the very low place given to the woman (Thukral, 1996). Almost all the institutes and project planning are male dominating, especially in developing countries. This may lead to widening the gender 
disparity. But the consideration and analysis of gender issues of displacement or resettlement is extremely important for a successfulness of development projects.

Other than bad effects, there could be good effects also with displacement such as creation of strong relationship within the family due to absence of other social relationships, more time to leisure, radical reordering of social relations and gendered relations. Human beings are much adaptable to changes depending on own attitudes and situation hence the pain of displacement is possible to be replaced with gains after a certain time period.

Sri Lanka has undertaken many large dam and diversion projects over the past 50 years. Of the projects, Mahaweli and Gal Oya development projects are the largest that resulted in forced migration and resettlement of individuals and families. However, there settlers of these projects benefited with more compensation compared to Deduru Oya project (MASL, 2017).No much studies have been conducted regarding gendered responses to resettlement stress in Sri Lanka.

\section{OBJECTIVE}

To identify the responses and adaptations of different gender groups to resettlement stress in the Deduru Oya reservoir project in Sri Lanka.

\section{METHODOLOGY}

This study was carried out within the Deduru Oya ${ }^{2}$ basin where a dam was built in 2014 to create Deduru Oya reservoir, displacing more than 1100 families. The Deduru Oya basin is a basin with water scarcity, while having an unexpected huge flow in rainy seasons. The project was initiated to store the excess water that is freely flowing to the sea in wet season to provide irrigation water within the basin, trans-basin water diversion, drinking water supply and stabilise flow to Ridi Bendi Ella irrigation scheme which is situated just downstream of the reservoir, and to generate hydropower. The reservoir is created at the place where main three tributaries meet together to form Deduru Oya (Figure 1).

Because of the Deduru Oya reservoir, some parts of Wariyapola, Mahawa, Ganewaththa and Maspotha Divisional Secretariat divisions (Divisional Secretariat division is an administration division) were inundated along with 2515 ha of settled agricultural lands. After the land acquisition, resettlement process was launched in Karuwalagaswewa, Kobeyiganee, Wariyapola, Ganewatte and Bamunakotuwa Divisional Secretariat divisions. There were many individual protests against displacement and resettlement, but only a few organized protests were taken place (Centre for Environmental Studies, 2003).

\footnotetext{
${ }^{2}$ Oya $=$ River
} 


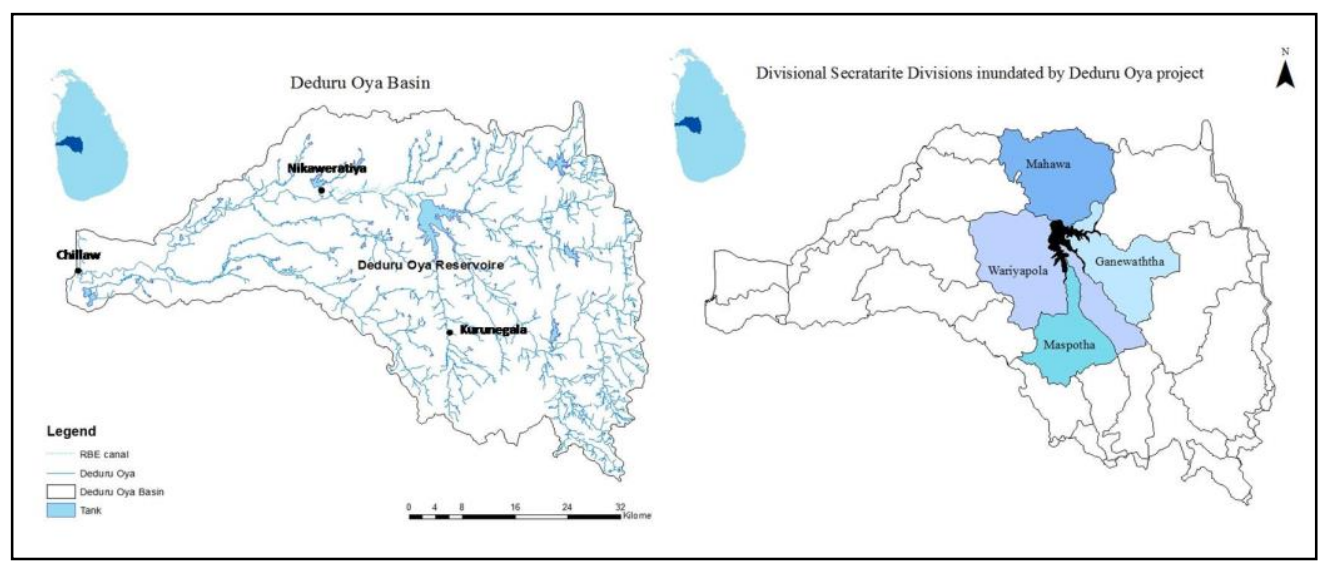

Figure 1. Deduru Oya basin, location of Deduru Oya reservoir and inundated divisional secretariat divisions

Firstly, a literature review was conducted and a classification of resettlement stress on seven themes was identified. In addition to that, a field visit was made for initial observations of the study area. Then government officers, especially officers from Deduru Oya Land Office were met to collect information on inundated areas, resettled areas and compensations given (Table 1). Since there were three compensation schemas, three resettled areas were selected for the study. Selection of respondents within one resettled area was carried out by simple random sampling. Then personal interviews were carried out with 30 respondents, and 21 respondents were selected for detailed interviews. From the detailed interviews, 12 case studies were formulated under the seven resettlement stresses identified. Supporting information was gathered through Key Informant Interviews (KII) and Focused Group Discussions (FGD). Field visits for these purposes were made between August 2015 and October 2015.

Table 1. Resettled areas and compensations received

\begin{tabular}{lll}
\hline Resettled area & $\begin{array}{l}\text { Divisional } \\
\text { Secretariat }\end{array}$ & Compensation \\
\hline Radawibendiela & Karuwalagaswewa 1 ac upland with all infrastructure facilities \\
& & (free) 1 ac of paddy land with irrigation \\
& facilities (free); LKR $316,000 /=$ basic \\
& payment (land preparation and build a toilet); \\
& Monthly payment up to a maximum of Rs \\
& $6,000 /=$ for 18 months; Allowance for \\
& transportation of household furniture
\end{tabular}

Thelahera farm Kobeyiganee $\quad 1$ ac upland with all infrastructure facilities (free); 1 ac (for cultivation) for the people who were applied for cultivation lands with a payment of undeveloped land value; LKR $16,000 /=$ basic payment (land preparation and

${ }^{3} 1 \mathrm{USD}=\mathrm{LKR} 153.48\left(\right.$ rate of $31^{\text {st }}$ October 2017) 


\section{Polgammane estate Wariyapola \\ Peter valley estate Ganewatte \\ Madurakaanchiya Bamunakotuwa estate}

Getakulandaestate build a toilet); Monthly payment up to a maximum of LKR 6,000/= for 6 months; Allowance for transportation of household furniture

$1 / 2$ ac upland with all infrastructure facilities (free); 1 ac (for cultivation) for the people who were applied for cultivation lands with a payment of undeveloped land value; LKR $8,000 /=$ basic payment (land preparation and build a toilet); Monthly payment up to a maximum of LKR $6,000 /=$ for 6 months; Allowance for transportation of household furniture

\section{RESULTS AND DISCUSSION}

Cernea (1996) found that there are seven consequences that could happen due to displacement of community by development programs. They are landlessness, joblessness, homelessness, food insecurity, marginalization, social disintegrations, and loss of access to common property. The forthcoming sections describe the above mentioned seven consequences or the stresses relate to displacement and resettlement in Deduru Oya reservoir project.

Most of the places and all the real names will not be mentioned in the following section due to ethical issues.

\section{Landlessness, homelessness and joblessness}

People, livelihood and the residence is a system existed and developed over a long period of time. This system is based on the land, and if the land is removed from the system, the system will collapse leading to homelessness and joblessness. Thus, displacement directly affects this system. Most livelihoods in rural areas of Sri Lanka are linked with land based natural resources. More than $50 \%$ of the people in the inundated area of Deduru Oya reservoir were farmers (Centre for Environmental Studies, 2003). Therefore, with the project displacement, access to all resources was lost and people had to find new resources to create new livelihood patterns.

\section{Case 1}

"Ajith" was working in the armed forces before the resettlement process. His family was in a village which was identified for resettlement due to inundation. They had a considerable amount of income from the coconut and other cultivations. When he got to know about the displacement of his family, he decided to leave the job illegally and came to the village to help his family. They refused to leave their inherited land and stayed at the same place even after others resettled. They fought with resettling officers for a fair compensation for their properties. After some negotiation, though they were not satisfied, they left the land and resettled in the given place. Ajith lost his job and the income from the cultivation. Therefore, they did not have any income source at the new place. Finally he came up with illegal ways 
of income generation such as selling timber in the forest reservation and poaching animals which are legally prohibited. These illegal livelihoods make a big threat for his life and his family.

\section{Case 2}

"Darshani" is Ajith's (refers to case 1) wife. She was not involved in cultivation or home gardening before the displacement. But after resettlement she had to find quick measurers to avoid her children from staving. Thereafter, she established a home garden containing various types of vegetables and fruits. As a result, she was able to find her daily food needs from the garden and sell the excess as well. Therefore, she has her own income source while reducing the burden of home economy.

Displacement has affected both Ajith and Darshani adversely. They have lost their land, home and family income, and were not satisfied with the relief provided. But their reactions to this situation ware completely different. Ajith left his permanent government job and turned to illegal and dangerous means of earning instead of looking for a livelihood that will suite to the newly settled area and the resources available; e.g. farming. But, Darshani was trying to cultivate anyhow and managing the resources available in the resettled place making some extra income as well. Therefore, Darshani is trying to adapt to the new environment while Ajith was still is struggling to find the same livelihood activities as before.

Ajith has demonstrated his risk seeking attitude as a male while Darshani was playing her traditional role of safeguarding the children.

\section{$\underline{\text { Case } 3}$}

"Kasun" is a 17 years old boy. He lived with his family in an area which was located at the edge of the reservoir and got inundated. Although his family was resettled in another area and received compensation and land, "Kasun" hesitated to leave the place. He did not leave the place though his home was half flooded. His relatives were encouraging and praising him for his braveness. Sometimes the water height within the house increases up to three feet but he manages to live there by making some arrangements. Even the electric wires are not removed from this house indicating his hope to be there forever.

\section{$\underline{\text { Case } 4}$}

"Menike" is a widow lived in an area which was supposed to be inundated. About two decades back she heard of the rumour of Deduru Oya reservoir and subsequent inundation of her village. She was a young widow at that time and had three children. She went to Divisional Secretariat office to clarify the rumour, expecting a difficult situation ahead. Then she knew that project will inundate her home in near future though the exact date was uncertain. Therefore, she worked hard, sold gold jewelleries and made arrangements for loans to make some money to buy a land from a safe area. Finally, she came up with a new house in a safe area. From the resettlement program she got a land in "Karuwalagaswewa" village, where elephant menace is common and she refused to accept it. She is happy about her decision and now she cultivate fruits and vegetables in the new land that she bought.

Kasun and Menike reacted to the situation in different ways. Kasun is still living in a half inundated house by risking his life. $\mathrm{He}$ is an unmarried man and has no family 
responsibilities. But Menike reacted thoughtfully in advance because she was the only person who is responsible for three other lives. Other than that, Menike, a widow had to go beyond the traditionally assigned gendered role. According to the case studies of Kasun and Menike, Menike had to go through many difficulties than Kasun because of losing her land, but she ended up with success compared to others, mainly due to gendered instinct as a women.

\section{Marginalization}

Simply, marginalization is keeping (someone) in a powerless or unimportant position within a society or group (Cernea, 1996).With respect to displacement, the marginalization of the people to be resettled begins when the land to be inundated is condemned and further development of the area is prohibited. Then marginalization goes forward with displacement and may not stop even with resettlement because of the problems arising with the native community.

\section{$\underline{\text { Case } 5}$}

Displaced people from an inundated village were resettled in a village called "Netiya" where native villagers were there. The initial unwelcome attitude of the native villagers continued and further expanded up to court cases. Death benevolence society is a well-established strong organization in each and every Sri Lankan village, with the membership of all villagers, mainly aimed to help in funerals of villagers. But a settler was not allowed to be a member in the existing death benevolence society of "Netiya" unless he or she pays LKR $30,000.00$ along with the approval of three committee members. This kind of rule does not exist for old community of the village or any other death benevolence societies in Sri Lanka.

Traditional New Year festival in April is the biggest cultural event in Sri Lanka aiming unity, and it consists of sub festivals. But in Netiya new settlers were not allowed to take part in the New Year festival, which shows the extent of marginalization of the resettled community. Therefore, the settlers had to form a separate death benevolence society and have a separate New Year festival in Netiya.

\section{$\underline{\text { Case } 6}$}

"Deepika" is a married woman. Before displacement she owned 3 ac of coconut land gifted to her as the dowry. Dowry is the property given by woman's parents at or after her marriage. According to the Sinhala ${ }^{4}$ community, the ownership of these properties can be given to the woman or her husband as per the choice of her parents. Deepika owned the properties under the dowry. But during the resettlement process she lost her property and her husband got the resettled land as the household head. The man of the family is considered as the household head indicating existence of the law of patriarchy in the system. Therefore, the compensation of the resettlement is given to man, assuming the benefits are transferred to other family members automatically.

According to the 'Case 5', on the one hand, settlers were eliminated from the main village society and became marginalized in the new resettled area regardless of gender. On the other hand, woman is marginalized further within the family by removing her ownership to land due the existence of the law of patriarchy.

\footnotetext{
${ }^{4}$ Sinhala is the main ethnic group of Sri Lanka
} 


\section{Food insecurity}

Displacement affects food security of people and finally leads to undernourishment that leads to long term health effects. Because, they have to leave their food crop which fulfilled their nutrient requirement and food habits they used to. Other than that their home economy collapses due to displacement and therefore the affordability of foods become low.

\section{$\underline{\text { Case } 7}$}

"Sarath" was a widowed farmer who cultivated coconut, paddy, fruits and vegetables. His family was self-sufficient throughout the year while having extra income. His land was not previously identified as a potential land to be inundated. His land was inundated at first filling of the reservoir in an unexpected way and got displaced. However, since the first stage of compensation and resettlement was over by this time, they had to struggle with the officers for compensation. According to the government land estimation officers, his lands were not pre-surveyed before the inundation and therefore it was difficult to evaluate and compensate. After a big struggle, he was able to obtain partial compensation including half an acre of land to resettle. Although his family has a house to live now, they do not have agricultural lands and they do not know any livelihood concept other than farming. Because of the poor economic condition of the family Sarath's daughter had to go to a Middle East as a house maid. In fact, all the people living in the surrounding areas where Sarath lives are settlers. There are less availability of fruits and vegetables in this area creating significant food insecurity. Further, there are no adequate places to buy food, making food inaccessible to the settlers. Therefore, there is a considerable gap of nutrient intake and food security.

\section{Case 8}

"Ranjani" is a resettled widow in the same area where Sarath (refers to Case 7) lives. She also lost the cultivation that her family owned, due to inundation. But after the resettlement she was trying to begin a home garden cultivation with vegetables, yams, leafy vegetables, and tree crops such as jack and coconut. Her home garden showed a considerable success. Now she is able to fulfil a part of the food and nutritional requirement of her family.

Sarath is still in anger and thinks about the land and commercial cultivation he had. Though he got half an acre of land he never tried for a home gardening for their food security. But Ranjani, who faced same problem, established a home garden to ensure food security of her family. Women in Sri Lanka are expected to play a reproductive role and therefore she has to ensure the health and nutritional status of the children. Therefore, Ranjani had to find a way for the food security of her family.

\section{Loss of access to common property}

Displacement removes people from their environment where they used to live and earn. Most of livelihoods and day to day needs of rural people depend upon common properties such as village tanks, rivers, forests and grasslands. Usually they have freedom to access any of these common properties. But resettlement leads to changes of access to common properties creating a problematic environment for livelihoods and day to day activities. 


\section{Case 9}

"Thilak" is a young farmer who lived closer to Kimbulwana Oya stream which is one of the main tributaries of Deduru Oya River. He had free access to water resources. After the project execution, his family had to resettle in Karuwalagaswewa where no any natural water sources. Because of the absence of irrigation water source he could not cultivate and therefore he has to work as a daily paid labourer for earning income.

\section{Case 10}

Prior to resettlement, "Nayana" used to collect drinking water from nearby common well. The water quality of that well was satisfactory according to her experience. But at the resettled area, there were no drinking water sources. Therefore, she dug a well in her garden, but the quality of the water was not good for consumption. She could manage other domestic activities with that water, but for drinking water she has to walk more than $1.5 \mathrm{~km}$ daily. Other than that, Nayana has to buy fire wood which she could access freely before resettlement.

Loss of access to common properties affected adversely both Thilak and Nayana. Even though Thilak lost access to water resources and could not cultivate, but he had to earn for his family. Therefore, he has to work as a labourer who was a farmer before. He is suffering mentally thinking of the self respect that he lost. Nayana's case is also similar to Thilak's regardless of the assigned gender role. But after the resettlement she had to bear many inconvenience situations in accessing the resources. She had to spend money for digging a well. She has to walk a long distance to collect drinking water and has to pay for even fire wood. She has to go through these difficulties in playing her reproductive roles.

\section{Social dis-integrity}

Usually within a village or a certain community, there is an established integrity and links among individual human beings, families or socially constructed groups. Displacement leads to collapse the existing pattern of social cohesion and integrity. Then resettlement may create further expansions of the problem because of creating a new social structure with the elements of collapsed society. However, displacement creates many social issues such as scattering family systems, disrupting labour markets, loss of cultural identities, take a part production systems, collapse local voluntary associations and mutual help. This disintegration possibly causes loss of recognition, goodwill and reputation and finally ends up with many psychological impacts.

\section{Case 11}

"Piyasena" is a 70 years old man who is resettled with his son and daughter-in-law. He lived happily before displacement with his wife, son, daughter-in-law, daughter, son-in-law and grandchildren. Son lived with him and daughter lived next to his house. But with the resettlement program Piyasena, his son and daughter received lands in completely different locations more than $20 \mathrm{~km}$ apart. Today Piyasena lives with his son and Piyasena's wife lives with her daughter. He is not fine because of dispersed family and especially his wife is not with him at this age. He is not healthy and suffering from several illnesses time to time, especially after displacement because the displacement created stress and led to poor physical and mental health. 


\section{Case 12}

"Babynona" is a 75 years old widow who is resettled after inundation. She is also suffering from the loss of social relationships due to displacement and resettlement but not much as others. She attends to religious activities every full moon day in a Buddhist temple which is located in a village next to hers. She meets a few of her old friends there. Other than that, there is very little marginalization to her from that temple society which is bound by religious norms and where mostly old women are present. In fact, she wants to be in a religious environment in this age.

Social dispersion led by displacement and resettlement makes adverse effects on the minds of the people who used to live together for a long time. Therefore, two cases (Case 12 and Case 13) to represent the aging community were selected. Piyasena is suffering a lot because of dispersion of his family. Though Babynona did not have her husband, her family and relatives were dispersed with the displacement. But to face the unpleasant time, she has chosen religious path and mingle with the new community. Usually villagers in Sri Lanka go to the temple in their own village for their religious activities. However, there are no rules or restrictions in attending other temples. Babynona got to know that some of her old friends are gathering in the village temple next to her village. Thus, going to that temple was an opportunity to meet her old friends. Other than that there is no any unwelcome condition in the temple. Therefore, even in a displaced and resettled situation she found her own way of adapting to the new environment.

\section{Summary of the general discussion}

Summary of the general discussion is presented in Table 2. With the displacement, in addition to her reproductive roles, a woman had to engage in productive roles as well to fulfil her family's immediate food and nutritional needs. Most of the time, the new environment was not conducive enough to play even her traditional reproductive roles such as fetching firewood and water and looking after her family, etc. Loss of neighbourhood and social disintegration affected the women more than the men. Anyhow, unlike their male counter parts, women were not aggressive when faced with difficult situations. Men tend to protest and campaign against the project and struggle for more compensation. But women look for quick solutions compared to men in finding opportunities for early adaptation. At times, both male and female are unable to manage with the consequences of displacement such as loss of access to common properties which are often not found in the resettled location.

Table 2. Summery of the adaptation strategies to resettlement stress by each gender

\begin{tabular}{|c|c|c|c|}
\hline $\begin{array}{l}\text { Resettlement } \\
\text { stress }\end{array}$ & Male & Female & Remarks \\
\hline $\begin{array}{l}\text { Landlessness, } \\
\text { Joblessness, } \\
\text { Homelessness } \\
\text { (Case 1,2,3 \& 4) }\end{array}$ & $\begin{array}{l}\text { Take time to fight } \\
\text { against displacement } \\
\text { and to get the } \\
\text { compensation } \\
\text { increased. } \\
\text { Not seeking immediate } \\
\text { solution for livelihood } \\
\text { disruption and } \\
\text { struggling for }\end{array}$ & $\begin{array}{l}\text { From the beginning of } \\
\text { the resettlement she } \\
\text { had to find a way to } \\
\text { take care of family } \\
\text { and feed her children } \\
\text { as soon as possible. } \\
\text { Women have to find } \\
\text { quick solutions in } \\
\text { feeding children and }\end{array}$ & $\begin{array}{l}\text { Female adapted to the } \\
\text { situation faster. } \\
\text { However, they have to } \\
\text { struggle through due to } \\
\text { the absence of } \\
\text { mechanisms to meet } \\
\text { their practical and } \\
\text { strategic needs in the } \\
\text { resettled environment. }\end{array}$ \\
\hline
\end{tabular}


permanent way of income generation which takes time

Marginalization Marginalized in the resettled environment

(Case $5 \&$ 6)

Food insecurity Takes time to fight against displacement

(Case $7 \& 8$ ) and to increase compensation. Tries to establish same selfsufficient livelihood system in the resettled land as well.

Loss of access to common property

(Case 9\&10)

\section{Had to give up} livelihood which he is used to and find a new job

$\begin{array}{ll}\text { Social } & \begin{array}{l}\text { Suffering from social } \\ \text { disintegrations } \\ \text { complaining }\end{array}\end{array}$

(Case 11\&12)

survive without risk.

Marginalized

(socially) in the resettled environment Marginalized (in terms of land ownership) within the home.

Attempt to establish at Female adapted to the least a home garden or situation well. back yard garden aiming food and nutritional needs of the family, children in particular.

Have to find new sources of water, firewood and other needs.

Have to walk more miles to find them reducing plenty of productive time.

Suffering from social disintegration and complaining. Join the religious community in the new environment.
Female affected more adversely by the situation, particularly by the existing law of patriarchy However, this stresses the women beyond their traditional reproductive roles.

Both, male and female are affected adversely. However, it didn't relieve her from carrying out her reproductive roles

Male and female are affected, however. female adapted to the situation well

\section{CONCLUSION}

Displacement and resettlement affected both men and women differently, but adversely. At times, both male and female are unable to manage with the consequences of displacement such as loss of access to common properties which are often not found in the resettled location. Women adapted to the resettled situation faster than men, since they have no choice other than adapting, because of the gendered roles and responsibilities to be performed at home. During the process of adaptation to the resettlement, most of the women are able to go for a kind of economic stability. They even play reproductive role like home gardening to feed their families until the men find a stable livelihood. Along with this quick beginning, women adapt better to the displacement and resettlement stress compared to men. But the traditional gender roles that she has to play place tremendous stress on her. No provisions have been made to meet her practical and strategic needs in the resettled environment. In addition, patriarchal way of land reallocation makes her marginalised within the family itself. 
The strength of social norms stands behind that situation. Usually the man gets priority in household matters including decision making and treated in a respected manner by women. They do not want to challenge men's rights or power.

\section{REFERENCES}

Acreman, M., (2000). Managed Flood Releases from Reservoirs: Issues and Guidance; a submission to the World Commission on Dams. Centre for Ecology and Hydrology, Wallingford, UK.

Asthana, V., (2012). Forced Displacement: A Gendered Analysis of the Tehri Dam Project in India. Journal of Economic and Political Weekly.

Caspary, G., (2007). The Impacts of Development-induced Displacement on Human Security. Human Security Journal, Volume 4.

Centre for Environmental Studies, (2003). Deduru Oya reservoir project - Environmental Impact Assessment report. Centre for environmental studies. University of Peradeniya, Peradeniya.

Cernea, M., (1996). Eight Main Risks; Improvishment and Social Justice in Resettlement. Environmental Department, World Bank.

Godamune, N., (2012). Development and displacement: the national involuntary resettlement policy (NIRP) in practice. Sri Lanka Journal of Social Sciences.

ILO/SEAPAT, (1998).Online Gender Learning \& Information Module.[Accessed on 2018. 04.13], Available at http://www.ilo.org/public/english/region/asro/mdtmanila/training/unit1/whatmenu.htm

Ledec, G. and Quintero, J.D., (2003).Good Dams and Bad Dams: Environmental Criteria for Site Selection of Hydroelectric Projects Latin America and the Caribbean Region. Environmentally and Socially Sustainable Development Sector Management Unit, The World Bank. Sustainable Development Working Paper No. 16

Mehta, L., (2011). The Settler and His Wife - Gender and Politics of Displacement. Deportees, Exiles and Refugees Deportate, esuli, profughe, 17, 25-43

Ministry of Resettlement. (2013). A framework for resettlement policy.Ministry of resettlement, Colombo.

Thukral, E., (1996). Development, Displacement and Rehabilitation: Locating Gender, in "Economic and Political Weekly", Vol. 31, no. 24, pp. 1500-1503.

UN., (1948). United Nations Universal Declaration on Human Rights 1948.http://www.jus.uio.no/lm/un.universal.declaration.of.human.rights.1948/portrait.a4.pdf WCD (World Commission on Dams). (2000). Dams and Cultural Heritage Management.World Commission on Dams Secretariat, Cape Town, South Africa. [Accessed on 2014.06.30], Available athttp://www.eca- 
Jayasiri et al.

watch.org/problems/asia_pacific/china/culture_dams_forWCD2000.pdf

MASL (Mahaweli Authority of Sri Lanka), (2017). Resettlement and population.[Accessed on 2018.04.14], Available at www.mahaweli.gov.lk 